\title{
worldview
}

A SOURHAL OF RELIGION AND INTERNÁtIONAL AFFAIRS

HOW UNITED IS LATIN AMERICA?

THOMAS MOLHAR

THE NUCLEAR OBSESSION:

II. PROLIFERATION, AND U.S. ALLIES

JACK WALKER

THE COLLEGE STUDENT

AND VIETHAM

JOHN P. LOVELL

\section{FOREIGN POLICY AND THE (LATE) GREAT SOCIETY}

How fares the Great Society? Will it still be with us at the next Presidential election? Alas, the prospects are not heartening. The Great Society was introduced into history under promising circumstances. Nurtured by the Kennedy Administration, and christened by Lyndon Johnson it was, thus, both the natural and the legitimate progeny of the New Deal. And it came at a time when the U.S. could, apparently, concentrate its major energies on domestic affairs.

In the first years of the Johnson Administration the early flood of legislation concerning civil rights, education, medical programs, the war on poverty, regional development, conservation, and the problems of city and ghetto carried much of the nation along in an approving if not enthusiastic consensus. Now that the flood has subsided and much of the completed legislation has produced less than it promised, the consenisus upon which the Great Society depended is breaking up.

One of the principal factors responsible for the breakup of that consensus is undoubtedly the war in Vietnam. There are a number of people who say that this need not and should not be. In the January issue of Foreign Affairs McGeorge Bundy attacks the idea that we must choose between present foreign commitments and domestic progress in the very title of his article, "The End of Either/Or."

We must, he writes, "carry on both these wide foreign activities and an active program of social progress at home. Those who resist such a domestic program can be expected to use the costs of Vietnam as an excuse for a domestic penny-pinching which would be as short-sighted as it is unnecessary. The recent election has probably strengthened the position of those who feel this way. They are wrong. $\therefore$ The work at home that we do not do now will simply have to be done later at a much greater cost.

"It is therefore an act of folly for any true liberal to argue that we must choose between Vietnam and social progress. The truth is the opposite. Americans who believe in the further development of the great new departures in edu- 
cation and health, in the battle for better cities, and most of all in the cause of really equal opportunity-those, in short, who care for social progress-should not strengthen the hands of their opponents by accepting the notion that we must choose between persistence in Vietnam and full budgetary support for a strong domestic program of action. It is not so, in economic or even in political terms."

This is well said and Mr. Bundy could find historical precedents for city-states and nations that developed great societies even as they contended with powerful forces abroad. But the position he has outlined is subject to question on two major grounds. First, no modem, industrialized nation has developed and elevated its domestic life at the same time that it has engaged in a substantial war.
Second, if legislation and the federal budget are fair indications, we may number among those who "choose between Vietnam and social progress" a large number of our national leaders. Faced with the alternatives of tax hikes or reduced public spending-and this is how the al. ternatives are seen-the latter is the politically palatable choice. And the sector of public spending that is most vulnerable includes exactly those new : programs that have not yet established themselves, those programs that most clearly mark advances in social planning. For psychological as well as political and economic reasons, the war in Vietnam directs resources from domestic programs. In assessing the cost of Vietnam we may have to include, therefore, the debility if not the demise of the Great Society.

\section{in the magazines}

A leading Brazilian newspaper, Ernst Halpexin reports in the New York Review of Books for December 29 , recently proclaimed in an editorial that "in Latin America, the Unitcd States had constituted itsclf into a mainstay of everything that is oligarchic, reactionary, stubbormly anachronistic; submissive, and sad." Anti-American expressions like this one, Halperin says in his review of several books on nationalism in Latin America, do not issue generally from the masses-from whom one would expect them if the situation were simply attributable to "the dominant role of American capital in the Latin Amercan economy." They are common, however, "in certain Latin American social groups not directly concerned with the economy-university and highschool students, intellectuals in general, and among the professional politicians who constitute the cadres of parties representing middle-class and workingclass interests. It is thus a phenomenon of the political and not the economic sphere, and of the elites, not of the masses," he maintains. "Its basic element is resentment of the lack of neutrality displayed by the United States in the power struggle between the oligarchic elites and the counter-elites of nationalist middle-class intellectuals, which has been going on in Latin America since the early years of the century."

Yet the economic and political spheres do come together to influence American policy in the area, $\mathrm{HaI}$ perin asserts: "It would of course be too much to expect the average Anerican business man in Latin America to remain meutral in the struggle between the oligarchies, the military, and the nationalist counter-elites. Although there are exceptions; business men as a group are not remarkable for a high level of political sophistication. They are unlikely to back a rabble-rousing Leftist in the hope that once in power, he will provide a bulwark against the very Bolshevism which he now appears to represent. . . Business men need political stability for the satisfactory conduct of their affairs, and they need it at once, not in some unforseeable future, it is thus perhaps inevitable that they should take a short-range view.

What is less inevitable, and far more harmful, is that the Latin American policy of the United States should so often have been determined by this same short-range view; that is, by the opinions and prejudices of the American business community in Latin America, It is not the link between the local oligarchies and American business circles alone, but the apparent ability of these business circles to determine Washington's Latin American policy which has given the United States the unfavorable image of being 'a mainstay of everything that is oligarchic, reactionary, stubbornly anachronistic, submissive, and sad.'

"The Alliance for Progress was an attempt to change this image. It failed because it asked too much, not of the Latins, but of American policy 